\title{
Entrelacs
}

Cinéma et audiovisuel

HS | 2012

Le post-humain et les enjeux du sujet

\section{Humain, bien trop humain}

\section{Carole Hoffmann}

\section{OpenEdition}

Journals

Édition électronique

URL : http://journals.openedition.org/entrelacs/298

DOI : 10.4000/entrelacs.298

ISSN : 2261-5482

Éditeur

Éditions Téraèdre

Édition imprimée

Date de publication : 2 février 2012

ISBN : 978-2296567177

ISSN : 1266-7188

Référence électronique

Carole Hoffmann, « Humain, bien trop humain », Entrelacs [En ligne], HS | 2012, mis en ligne le 01 août 2012, consulté le 20 avril 2019. URL : http://journals.openedition.org/entrelacs/298 ; DOI : 10.4000/ entrelacs.298

Ce document a été généré automatiquement le 20 avril 2019.

Tous droits réservés 


\title{
Humain, bien trop humain
}

\author{
Carole Hoffmann
}

1 Le texte complet de cet article est publié dans l'ouvrage :

Post humain et les enjeux du sujet

Editeur : L'HARMATTAN (2 février 2012)

Collection Ouverture Philosophique

ISBN-10 : 2296567177

ISBN-13 : 978-2296567177

\section{RÉSUMÉS}

La période contemporaine marque une rupture dans la façon dont l'être humain va agir sur luimême et sur son espèce, et dans la façon dont il va envisager son évolution en relation avec l'environnement. Il a toujours fait en sorte d'agir sur son bien-être, à la fois en s'entourant de dispositifs qui lui permettent d'améliorer son confort, sa santé et son hygiène, mais aussi en magnifiant l'image qu'il donne à voir, et en estompant les marques du fil du temps vers son inévitable dissolution.

\section{AUTEUR}

\section{CAROLE HOFFMANN}

Maître de conférences en arts plastiques, responsable du master 2 professionnel Création Numérique, Université de Toulouse 2 Le Mirail. 